ОСИНЮК Варвара Александровна - аспирант кафедры российской политики факультета политологии Московского государственного университета им. М.В. Ломоносова (119991, Россия, 2. Москва, Ломоносовский пр-кт, 27, корп. 4 «Шуваловский»; O.varvara@таil.ru)

\title{
ОСОБЕННОСТИ РАЗВИТИЯ ЭЛЕКТРОННОЙ ДЕМОКРАТИИ В МОСКВЕ
}

Аннотация. В статье рассматривается опыт правительства Москвы по имплементации новых форм электронной демократии. Автор изучает процесс первого пилотного электронного голосования на выборах депутатов Московской городской думы, анализирует процесс цифровизации в рамках города, его влияние на социально-экономическую и общественно-политическую сферы. В статье обоснована гипотеза, что повышение уровня роботизации в секторе государственного управления, использование новых технологических решений и инновационных разработок обеспечат более высокое качество и прозрачность осуществления государственных услуг.

Ключевые слова: электронная демократия, цифровизация, органы государственной власти, электронное голосование, правительство Москвы

$\mathrm{C}$ егодня в научном мире эксперты активно обсуждают проблемы электронной демократии (e-democracy), интернет-демократии (internet-democracy), виртуальной демократии (virtual democracy), цифровой демократии (digital democracy), кибердемократии (cyber-democracy) и то, как эти трендовые концепты могут парадигмально менять устои политических процессов и информационно-коммуникационных технологий во всем мире. Россия на сегодняшний день активно участвует в создании единой государственной цифровой платформы, которая позволит реализовать демократические принципы на новом, более качественном уровне [«Умный город»... 2018: 175].

Согласно указу Президента РФ от 9 мая 2017 г. № 203 «О Стратегии развития информационного общества в Российской Федерации на 2017-2030 годы» и утвержденной председателем правительства Российской Федерации программы «Цифровая экономика Российской Федерации» в стране начали активно создаваться условия институционального и инфраструктурного характера для внедрения различного уровня технологий в социально-экономические и общественно-политические сферы. К 2021 г. основные государственные услуги должны быть доступными для граждан и иных участников процесса в электронном виде. Москва обладает необходимыми научными, экономическими и технологическими возможностями для того, чтобы осуществлять экспериментальные проекты в рамках городского управления. Стоит отметить, что в 2017 г. Москва впервые попала в топ-7 интеллектуальных мегаполисов мира, войдя в число финалистов премии исследовательской организации Intelligent Community Forum [Василенко 2019а: 92].

Анализируя особенности развития электронной демократии в Москве, важно на глубинном уровне понимать, что такое электронная демократия сегодня. Ведь это не новый тип или вид формы правления, это конкретные практики политической деятельности органов государственной власти, которые используют набор digital-инструментариев, применяя их для реализации определенных демократических процедур [Василенко 2019б: 68]. Применение современных информационных технологий в политике помогает преодолеть различного рода ограничения при принятии решений. Но наряду с процессом глобальной цифровизации по-прежнему не теряет своих позиций аналоговая форма участия в общественно-политических процессах. Говоря об углублении процесса цифровизации в Москве, стоит отметить, что с 2012 г. было создано 
несколько глобальных пробных проектов и подразделений в этом направлении, таких как Управление по применению информационных технологий и развитию электронной демократии в рамках Администрации Президента, сайт Российской общественной инициативы, платформа «Открытое правительство», государственная программа города Москвы «Информационный город», интернет-площадка «Активный гражданин», концепция «Умный город - Москва». Изучение и применение цифровых технологий в стране в общественно-политической сфере вышло на новый уровень, задача сегодняшнего дня - поиск наиболее эффективных, качественных форм взаимодействия органов государственной власти, институтов гражданского общества и субъектов предпринимательской деятельности. Применение цифровых технологий на уровне такого диалога позволяет преодолеть временные и пространственные ограничения.

В столице в 2019 г. был принят закон города Москвы «О проведении эксперимента по организации и осуществлению дистанционного электронного голосования на выборах депутатов Московской городской Думы седьмого созыва». Эксперимент был проведен в 3 округах города. Технической поддержкой в столице занимался Департамент информационных технологий города Москвы (ДИТ). Голосование проходило на базе технологии блокчейна. На современном этапе развития технологий данный способ хранения и передачи данных является самым надежным и безопасным. Более $90 \%$ избирателей обеспечили явку на выборы в рамках электронного голосования в сентябре текущего года (около 10000 чел.), в то время как аналоговым способом проголосовали около 20\% избирателей. Эти цифры свидетельствуют о готовности столичного населения идти на подобного рода эксперименты и проявлять гражданскую активность любым технически доступным и удобным способом. Такой вид голосования напрямую поможет воспользоваться избирательным правом гражданам с ограниченными возможностями (сообществу инвалидов, например), гражданам, проживающим за границей. Для молодого поколения, для которого применение digital-технологий - привычный процесс, осуществить волеизъявление электронным способом также будет очень актуально. Сокращение бюджетных средств на организацию выборов, ускоренный процесс подведения итогов, надежность технологий подсчетов - это неполный перечень положительных промежуточных итогов при проведении электронного голосования.

Основной целью данного экспериментального проекта является создание для жителей мегаполиса дополнительных возможностей реализации избирательного права. Параллельно с достижением данной цели идут процессы усиления недоверия к данному инструментарию электронной демократии. В процессе дистанционного голосования самыми важными являются три составляющих - тайна голосования, информационная безопасность, надежность идентификации личности. Эти принципы закреплены в Конституции РФ. И есть основания полагать, что данные постулаты не будут в полной мере реализованы на практике при отправлении электронного избирательного права. Правительство Москвы слабо инициирует процесс легитимации данного процесса, что серьезно подрывает устои конституционного строя в целом. В законопроекте о внедрении системы отсутствуют положения, которые отражают возможность контроля общественности над процессом. Новации такого уровня могут создать потенциальную возможность для фальсификаций результатов выборов, в данном случае - для правящей власти: это принудительное голосование, пересчет и накрутка голосов, непрозрачность системы в целом и пр. Безопасность еще пока остается довольно болезненным вопросом для Департамента информационных технологий Москвы, поскольку уровень защиты от киберугроз очень 
невысок, что в целом сводит к минимуму дальнейшие перспективы развития. Информация выступает в качестве единственного носителя волеизъявления, и она может быть изменена в любой момент. На данном этапе открытым остается вопрос наблюдателей, членов комиссии, ведь отсутствие документации, отсутствие доступа к программе и ее функционалу лишают оппозицию возможности опровержения результата выборов. Любые инновационные методы должны быть подконтрольны обществу, в противном случае они будут служить интересам правящей власти. Согласно предварительным планам Центральной избирательной комиссии дистанционное голосование будет проходить повторное апробирование на выборах депутатов Государственной думы в 2021 г. Оценивая перспективу федерального масштаба такого проекта, стоит сказать, что данная новация позволит власти получить десятки и сотни тысяч дополнительных голосов.

Стоить отметить, что использование нового инструментария в ближайшем будущем потребует дальнейшей кодификации правил, хотя бы в части техноэтики (сохранение морально-нравственных начал в условиях технократического пресса), ядром которой на сегодня должна выступить свобода пользователей в сети, которую граждане должны использовать в качестве мотивации для активной реализации своих прав и обязанностей [Digital Media... 2017: 124].

Надо понимать, что проблема ограничения свободы человека при развитии новых технологий - одна из вечных в истории человечества. И предложение обменять часть свобод на безопасность неизбежно возникает при каждом новом повороте в развитии технологизации общественного пространства [«Умный город»... 2018: 54]. Вопрос технологической революции сегодня - это, прежде всего, определение роли и места самого человека, его потенциала в социогуманитарной, политической и естественно-природной плоскости [Чернышов 2018: 20]. Следовательно, антропоцентричный вектор должен быть в основе диалога власти и остальных участников процесса.

Сегодня можно сказать лишь о некоторых промежуточных итогах цифровизации. Так, создана система городских решений «ВМЕСТЕ» - это 3 интерактивных самостоятельных цифровых проекта по взаимодействию власти и жителей, получению обратной связи с населением города Москвы, которые были созданы по инициативе мэра С.С. Собянина. Эти проекты возникли как часть новой философии управления городом при которой власть и горожане совместно управляют Москвой. На платформе Crowd (краудсорсинг) каждый зарегистрированный в системе житель столицы может предложить любую идею по благоустройству города. Экспертное сообщество отбирает наиболее перспективные идеи, далее идет обсуждение и голосование жителей. С начала работы платформы более 180000 горожан приняли участие в проектах; было предложено более 96000 идей, реализованы в полном объеме 19 значимых проектов.

Другая московская платформа «Активный гражданин» насчитывает более 2600000 тыс. участников. Со времени запуска программы были проведены около 4200 голосований и реализованы более 3000 решений, т.е. ежемесячно реализуется 30-40 решений, или практически каждый день в городе воплощаются решения, принятые москвичами в проекте. Активные москвичи выбирают проекты благоустройства улиц, парков, дворов, дизайна метро, озеленения города, открытия детских центров при спортивных школах и многое другое. В 2016 г. компания PricewaterhouseCoopers $(P w C)$ провела независимый аудит деятельности проекта, который не выявил отклонений в реализации целей программы.

И третья платформа, «Наш город», позволяет населению города оперативно уведомлять городские органы власти о конкретных проблемах, которые затра- 
гивают сферы транспорта, инфраструктуры города, госучреждений и общественных организаций, безопасности и многие другие. Ждать ответа придется всего лишь неделю, что существенно облегчает планирование своего времени.

Из неоспоримых преимуществ процесса цифровизации демократических процедур в Москве можно выделить такие, как:

- интеграция платформ с существующими программными и аппаратными средствами, работа с открытыми и закрытыми данными;

- вовлечение всех заинтересованных участников в улучшение качества городской среды;

- совершенствование законодательства;

- мониторинг состояния системы жизнеобеспечения города в реальном времени;

- повышение безопасности жителей и готовности к ЧС;

- повышение качества городского управления и снижение затрат.

Успешность таких экспериментов в отдельно взятом городе дает толчок инициации таких процессов и в регионах всей страны. Это, безусловно, гарантирует улучшение качества жизни и эффективность взаимодействия органов государственной власти, бизнеса и институтов гражданского общества. Цифровизация в связке с человеческим капиталом поможет вывести осуществление демократических принципов управления на качественно более высокий уровень.

\section{Список литературы}

Василенко И.А. 2019а. «Умный город»: основные направления и перспективы смарт-стратегии развития столицы. - Власть. Т. 27. № 3. С. 91-95.

Василенко И.А. 2019б. «Умный город» в цифровом обществе 5.0: социальнополитические и гуманитарные риски цифровизации общественного пространства. - Власть. Т. 27. № 5. С. 67-73.

«Умный город» ХХІ века: возможности и риски смарт-технологий в городском ребрендинге (под ред. И.А. Василенко). 2018. М.: Международные отношения. $256 \mathrm{c}$.

Чернышов А.Г. 2018. Стратегия и философия цифровизации. - Bласть. Т. 26. № 5. C. 13-20.

Digital Media Integration for Participatory Democracy (ed. by R. Luppicini, R. Baarda). 2017. IGI Global. 259 p.

\section{FEATURES OF THE DEVELOPMENT OF E-DEMOCRACY IN MOSCOW}

\footnotetext{
Abstract. The article discusses the experience of the Moscow Government in the implementation of new forms of e-democracy. The paper gives an analysis of the process of the first pilot electronic voting for deputies to the Moscow City Duma and analyzes digitalization process within the city, its impact on the socio-economic and socio-political spheres. The author substantiates the hypothesis that increasing the level of robotics in the public administration sector, the use of new technological solutions and innovative developments will provide higher quality and transparency of public services.

Keywords: e-democracy, digitalization, government departments, electronic voting, Moscow Government
} 